\title{
Scheherazade in Istanbul: A Study of the Popular Turkish TV Series Binbir Gece
}

Maryam Ghorbankarimi, Lancaster University

\begin{abstract}
One Thousand and One Nights is a composite, transnational work, consisting of popular stories originally transmitted orally within its embedded cultures and developed over several centuries. Ever since its translation into European languages in the nineteenth century, or perhaps even before, it has been adapted and appropriated into different forms and mediums and thus has reached different corners of the world. This project was inspired by the level of popularity of One Thousand and One Nights, often known as the Arabian Nights, in the world today. Although only a relatively small number of people might have read all the tales, we can safely assume that most people do have an idea of what the Nights are, whilst some could even name one or two films, series, or cartoons that they think are based on the Nights. Indeed, only a very limited number of stories included in editions of the Nights have been adapted into films or TV series. There are two main characteristics of the Nights that help identify adaptations and adoptions in popular culture: embedded storytelling using a frame tale, and the 'feminist', emancipating heroine Scheherazade. The popular Turkish TV series Binbir GecelOne Thousand and One Nights (2006-09), which this article focuses on, not only makes use of these two popular features; it also offers a fresh and contemporary adaptation of the frame story of Shah Shahriyar and Scheherazade and elements from many other tales from the Nights, such as the emphasis on the importance of education for women, or the evil of cunning women. After analysing the degree of adaptation of the frame story in this series, this article sheds light on its global reach, reception and popularity.
\end{abstract}

Key words: One Thousand and One Nights, The Arabian Nights, Adaptation, Soap Opera, 
Turkish Television Series, Scheherazade.

\section{Scheherazade $^{1}$ in Istanbul: A Study of the Popular Turkish Television Series Binbir Gece}

Dostum kadınlara inanma, vaatlerine gül geç. Kadınlar güya aşktan söz ederler, oysa hainlik onları sarıp sarmalayip giysilerinin titreşiminde şekillenir. Adem'i cennetten kovdurmak için iblisin kadını kullandığını unutma. Bir gün aşka düşersen aşıkların çılgınlığına kapılmayacağım deme sakın [...] Kapılırsın! Çünkü kadınların baştan çıkarıcılığından yakasını sıyırmış bir erkek olmayacak birşeydir. ${ }^{2}$ (Binbir Gece, Episode One)

${ }^{1}$ This article makes use of three spellings for the name of the storyteller in One Thousand and One Nights to distinguish the different texts: Scheherazade (the common spelling in Western texts); Şehrazat (the Turkish spelling); and Shahrzād (transliteration of the Persian pronunciation).

2 'Do not put your trust in women/ Or believe their covenants.

Their satisfaction and their anger/ Both depend on their private parts.

They make a false display of love/ But their clothes are stuffed with treachery.

Take a lesson from the tale of Joseph/ And you will find some of their tricks.

Do you not see that your father, Adam/ Was driven out from Eden thanks to them?'

Another poet has said:

'Blame must be matched to what is blamed/I have grown big, but my offence has not. I am a lover, but what I have done/Is only what men did before me in old days.

What is a cause for wonder is a man/ Whom women have not trapped by their allure?' 
Binbir Gece/One Thousand and One Nights (2006-09), opens with Rimsky-Korsakov's

Scheherazade (1888) theme over the credit sequence, an aerial shot of some of the most iconic Istanbul monuments at night, including the Maiden's Tower, a recurring motif throughout the series. While the music continues, the credit sequence dissolves into Kaan (Efe Cina)'s room, where we see the little boy from behind, jumping to catch the shadow of the flying bird made by his mother against the wall. The camera then pans up to reveal his mother, Şehrazat (Bergüzar Korel), holding her son's hand while a male voiceover recites the above passage from the introduction of the original source material. This juxtaposition between Şehrazat, the young mother, with the words 'My friend, do not put your trust in women...', and the conversation that follows between Onur Aksal (Halit Ergenc) and Kerem İnceoğlu (Tardu Flordun), the Shah Shahriyar and Shah Zaman counterparts in this adaptation, is how this modern adaptation of One Thousand and One Nights begins.

\section{Adaptions of One Thousand and One Nights}

One Thousand and One Nights is a multicultural and multi-mediated literary work, which has been reshaped and remediated several times in the past 2500 years. When we think about the retranslation and reinterpretation of literary texts, One Thousand and One Nights comes to mind as one of the most translated, retranslated, reinterpreted and remediated texts in world literature and visual arts. It is an example of world literature par excellence, since it has been

(Lyons, Lyons and Irwin 2008: 3). The lines that are scored through are missing from the Turkish text in Binbir Gece. 
created by numerous storytellers and authors in different countries. It was orally transmitted, then written and translated into various Eastern and Western languages. The journey of the Nights over time made the work a popular text in different artistic, literary and visual mediums. It has taken local flavours and even new titles in each host culture. In addition, many authors, playwrights, music composers and filmmakers were inspired by the Nights.

The number of screen adaptations of One Thousand and One Nights are surprisingly few. Among the existing titles are some unique and quite stylized films such as Il fiore delle mille e una note / Arabian Nights, the 1974 Italian adaptation by Pier Paolo Pasolini. Since the Nights as we have them today are based on oral and therefore popular tradition, I am interested in popular rather than the artistic adaptations (Starkey 2006: 17); popular ones include Douglas Fairbanks's silent golden-era Hollywood swashbuckling film The Thief of Baghdad (Walsh, 1924), Bugs Bunny's third movie 1001 Rabbit Tales (Freleng, 1982) and, of course, Disney's Aladdin (Celments, 1992) and its recent live action remake Aladdin (Ritchie, 2019).

The popularity of One Thousand and One Nights in the world today may not be directly due to the text or the tales themselves, but rather to a historical consciousness and terms referring to the work, which have developed since its various early translations in Western European languages. A single Google search of the number '1001' reveals many websites that have used this popular alliteration attributed to the Nights to imply the innumerability of what they offer. Indeed, the intention of the early compilers of the tales for the Nights was the same; when using ' 1001 ' they never meant literally to refer to the number of the nights, but rather to imply the innumerable numbers of nights (Marzolph 2007: 203-4). Although only a very small number of people might actually have read all the tales, one can safely assume that most people still have an idea of what the Nights are. And a few could even name one or two films, series, or cartoons that they think are based on the Nights. However, only a very limited number of tales and story cycles included in editions of the Nights have 
been adapted for films or TV series.

Besides specific stories, such as those associated with Sinbad the Sailor or Aladdin (a story that was not included in the original corpus) (Marzolph 2007: 332), the other two main characteristics of the Nights that help identify adaptations and adoptions in popular culture are the embedded storytelling device of a frame tale, and the 'feminist', emancipated heroine Scheherazade. It is almost as though today the title One Thousand and One Nights and the name Scheherazade have become two separate and, in some ways, synonymous entities coming from the same body of works.

Mohsen Mahdi asserts that the frame story of One Thousand and One Nights, with its gender crossing and collaboration between the slaves and the women of the palace, represents a site of rebellion against 'the conventions that had established their inferior position' (cited in Al-Musawi 2004: 345). This view can be contained within the premise that Scheherazade herself sustains a feminist presence of wit, resourcefulness, and charm, which proves to be disarming and challenging to patriarchal practices and assumptions. Judith Grossman argues that the story of Shah Shahriyar and Scheherazade presents in an early form the problem that male-dominated cultures in recognising female subjectivity (1980: n.p). It is therefore relatively easy to find different Scheherazade-like characters in any modern tale that has given agency and voice to their prominent female characters. As Fedwa Malti-Douglas asserts:

Were the Arabic Shahrazad to awaken, like some fairy tale princess, centuries after she first wove the stories in The Thousand and One Nights, she would undoubtedly be surprised by her numerous literary transformations. (Malti-Douglas 2006: 40) 
The coded meaning that Scheherazade bears has been the point of departure for many adaptations of One Thousand and One Nights. This is not just confined to the Western adaptations, but can be found in the embedded cultures of the Nights as well. For example, the Iranian television series Shahrzād (2011-18), set in 1950s Iran, has very little to do with One Thousand and One Nights per se, except that it has borrowed this name for its protagonist in order to instigate the right reception and expectation from the viewers. In this series, Shahrzād (Taraneh Alidoosti) begins as an oppressed but well-educated female figure trying to influence and transform her patriarchal surroundings. To complete this image there is a scene in an early episode in which this Shahrzād becomes a complete embodiment of the One Thousand and One Nights storytelling Scheherazade, reading the frame story of the Nights for her husband while lying in bed.

\section{Binbir Gece (2006-09)}

Binbir Gece, the case study of this article, was directed by Kudret Şabanci, who previously had a few other television mini-series and series to his credit. He has also directed one of the five segments of an episodic film with an interconnected tales set in modern-day Istanbul, Anlat Istanbul/Istanbul Tales (2005). The segments were loosely based on the fairy tales Snow White, Cinderella, The Pied Piper of Hamelin, Sleeping Beauty, and Little Red Riding Hood. His keen interest in fairy tales is also evident in Binbir Gece in his use of the Maiden's Tower as the symbol of the unreachable, unattainable woman Onur is trying to possess (We Love Istanbul 2017).

While the popularity of this series is evinced through its widespread reception and what can be seen in online forums, few scholarly papers have addressed its reception, and a close reading and critical study of the series has not, until now, been offered. Mentions of this series, along with other popular Turkish TV series, are limited to articles and studies on the 
political and cultural influence of Turkey in the Middle East and Balkans since the 2000s. Binbir Gece was produced at the height of popularity of Turkish TV series in these regions. By December 2008, the number of private national channels in Turkey totalled twenty and their market value had reached \$6.6 million (Emre Cetin 2014: 2464). Despite an increased interest in reality and game shows, eleven of these channels continued to broadcast Turkish series: 'As with the telenovelas of Latin American and Spanish-language television (Lopez, 2002), dramas became the sine qua non for Turkish television' (Emre Cetin 2014: 2464).

The Turkish Radio and Television Corporation (TRT), the national TV broadcaster, established its first channel in 1968. This maintained total monopoly until the 1990s, when some private channels began broadcasting via satellite. These new private channels at first showed only news and entertainment programmes, foreign (largely Hollywood) series, and 'Yeşilçam' (films from the Turkish Golden era lasting from the 1950s to the 1970s). It was only in the second half of the 1990s that the demand for locally produced series increased. This led to the formation of an industry of a considerable size by 2005 (Behlil 2010: 3).

A significant proportion of the Turkish TV series were dubbed into Arabic and exported to other Middle Eastern countries, which provided a new source of funding for these private Turkish channels (Behlil 2010: 3-4). Most of these series were entertaining and focused on 'stories about the Istanbul elite and their problems with love, sex, marriage, family, money, violence, social class, and organized crime' (Kraidy 2013: 23). Discussing the reasons behind the popularity of Turkish dramas in the Arab world, Kraidy and Al-Ghazzi assert that, whilst the uneasy historical and colonial past between the Ottoman Empire and the Arab World and the existing linguistic diversity between them cannot be overlooked, 'Turkey and

\footnotetext{
${ }^{3}$ According to a report released by the Istanbul Chamber of Certified Public Accountants (ICCPA), eleven national networks broadcast 63 series in 2008 (Behlil 2010: 3-4).
} 
the Arab world share common histories and memories, and therefore will gravitate towards similar assemblages of the modern' (Kraidy 2013: 25). Out of all the popular Turkish soap operas that have found an audience in the Arab world, Binbir Gece seems to be the least surprising one. One could argue that the One Thousand and One Nights tales are one of the unique cultural products that connects all peoples of the Middle East, from the Arab World to Turkey, Iran and beyond. With respect to Iran and the Persian-speaking world, the popularity of the Turkish series can be perceived as a direct response to the increasing sanctions on Iran from 2010. According to Partovy, 'millions of Iranians during (and after) the sanctions era nightly watched foreign and especially Turkish melodramas shown on offshore satellite networks': it can be argued that this connected them with 'consumerist utopias just beyond their borders where glamorous characters engaged in steamy love affairs, freely travelled around the globe, and indulged in the latest fashions and technology (Partovy 2018: 117).

The reach of Turkish series would extend from the Middle East and Balkans to greater Slavic countries, Russia and Greece. Although relations between Turkey and Greece have a somewhat tenuous history, it seems that a television love story between a young Greek man, Nikos, and a young Turkish woman named Nazli had over the Greek audience's heart. The Turkish series entitled Yabancı Damat (Foreign Groom), produced for and aired by Turkey's

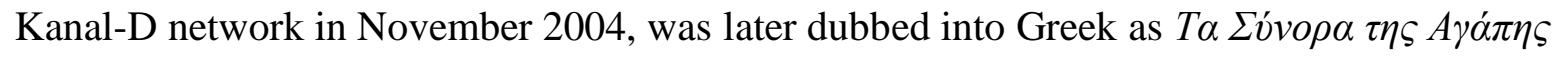
(Borders of Love). This was followed by other Turkish TV series including Binbir Gece in 2010, which was reported to have more than one million viewers (Mihalakopoulos 2013:18485). Considering the scale of their success and transnational reach, it is not surprising that one of the most prominent film and TV-streaming platforms, Netflix, has also incorporated a large number of Turkish series in its library, including the first fifty episodes of Binbir Gece.

\section{Binbir Gece: a Turkish Soap Opera}


Binbir Gece, which can be categorized as a soap opera, not only makes use of the two aforementioned popular features of the Nights, namely the embedded storytelling and Scheherazade, but it also offers a fresh and contemporary adaptation of the frame story of Shah Shahriyar and Scheherazade, and elements from many other tales from the Nights, emphasizing the importance of education for women and of being wary of the evil of cunning women. In a similar way to how the narrative of the Nights is rooted in oral culture, the soap opera genre is rooted in contemporary popular culture, and has a purpose to entertain; as a result, it has at times been marginalized as a field of study. One can argue that One Thousand and One Nights itself was also condemned to a similar fate due to it being labelled as 'popular literature'. The title 'soap opera' alone binds these shows to what society has held to be unimportant. The name derives from how these programmes were shown on daytime television, intercut with soap advertisements, but also associations with the high art of opera, thus promoting the misguided, sexist premise that soap operas belong exclusively to women, and that the genre, therefore, reflects a sentimental, escapist, and/or hysterical sensibility (Nachbar 1992: 446).

Very similar to the way the One Thousand and One Nights are structured, soap operas reject traditionally structured plots, whereby a character is embroiled in a conflict, which leads to an integrated series of crises and one concluding climax. Stories in soap opera mirror the chaotic order of life: conflicts may develop quickly, and then suddenly be suspended; certain conflicts can be 'put on the back burner'; characters' problems may be solved arbitrarily without a climax; or a character may dominate the narrative and then suddenly become irrelevant. Sometimes a character in the One Thousand and One Nights will begin telling other characters a story of his or her own, thus becoming a narrator, and that story may have another one embedded within it. For a time, therefore, the initial story takes a secondary position, resulting in a richly layered narrative texture. For instance, in Binbir Gece, Şehrazat's father- 
in-law's family and especially the other son, Ali Kemal (Ergün Demir), and daughter-in-law, Füsun (Yonca Cevher), have their own story within which Ali Kemal cheats on Füsun and begins a relationship with Cansel (Füsun Kostak). Later when Cansel and Ali Kemal break up, we continue following Cansel into her new life and her relationship with a new man. The storytelling device grows from the trunk into several smaller branches. This kind of web linking characters for a short period of time is also very common in soap operas and typically, if one misses a few episodes and re-joins the series it is difficult to follow at first because the stories' development is not linear. In soap operas, ambiguous characters can take an appealing shape for a time and then find themselves remoulded in the image of evil; and very sympathetic characters can turn bad.

Tania Modleski contends that soap operas may prove to be the most (if not the only) feminist televisual form. Employing Roland Barthes' hermeneutic code, she sees feminist potential in three aspects of the soap opera: its disrupted narrative form, its avoidance of narrative closure, and its construction of a fragmented spectatorial viewpoint (Modleski 1979). I would argue that these characteristics have strong parallels in the One Thousand and One Nights and therefore in Binbir Gece. A narrative usually has a beginning, a middle, and an end; while a soap opera only has a diegetic middle: enigmas without permanent resolutions, the origins of which are frequently lost in the overabundance of narrative. As Laura Mulvey writes, 'the strength of the melodramatic form lies in the amount of dust the story raises along the road, a cloud of over-determined irreconcilables which put up a resistance to being neatly settled in the last five minutes' (Mulvey 1989: 54). Soap opera, obviously, has no 'last five minutes'. Ideological conflicts are never fully reconciled. Jeremy Butler, quoting Ellen Seiter, while referring to Umberto Eco's distinction between 'closed' and 'open' texts, comments on the significance of the soap opera's disrupted and reconstructed narrative: 
The importance of small discontinuous narrative units which are never organized by a single patriarchal discourse or main narrative line, which do not build towards an ending or closure of meaning, which in their very complexity cannot give a final ideological word on anything, makes soap opera uniquely open to feminist readings. (Butler 1986: 54)

Accepting this argument about the structure of soap opera which invites a feminist interpretation is what makes soap opera an appropriate medium for delivering a contemporary adaptation of one of the earliest examples of a feminist character in world literature. In the frame story, in contrast to the Nights themselves, the voice of the narrator is not Scheherazade's voice; instead, Scheherazade is the heroine of the text, or she is part of it herself. At the same time the frame story is what Eva Sallis has called the 'signature story' for all the stories of the Nights; in other words, even if we forget every detail of each story we would still remember Scheherazade's story (Sallis 1999: 87). Binbir Gece, while depicting the frame story of the Nights in which Scheherazade is not yet the storyteller, has also incorporated many of the stories from the Nights in its tangled web of short and long parallel stories over ninety nights.

Binbir Gece's first episode is the most telling, as it sets up everything that will resolve slowly in the next 89 episodes. Şehrazat's deceased husband's family had disowned him for marrying her, and her wealthy father-in-law, Burhan Evliyaoğlu (Metin Cekmez), refuses to give her the $\$ 150,000$ she desperately needs in order to pay for her son's bone-marrow transplant. It is also revealed that Şehrazat, who has recently been hired at Binyapi, Onur Aksal and Kerem İnceoğlu's firm, in her interview had concealed the fact she is a single mother to make sure they would hire her without prejudice. We also learn that Onur's mother still respects her dead husband and holds a religious reception on the anniversary of his death, 
even though he was cheating on her and — shockingly — had died in his lover's bed. In response to Onur's praise of his mother, Kerem says that Onur's mother is also a woman, linking this to their earlier conversation in the opening sequence. But Onur firmly rejects this notion and says she is a mother, not a just a woman. To Kerem's comment that every woman can be a mother, Onur replies that naturally every woman is capable of giving birth to a child, but not all are capable of being a 'mother'. What is fascinating in this adaptation is the distinction Onur makes between a woman and a mother. As in the Nights, regardless of the discrepancy in the number of children Scheherazade has given birth to at the end of the story or in the epilogue, one way or another in all the different versions it is conveyed that Shahriyar has spared her life either for his growing love for her or for the sake of her motherhood (Enderwitz 2004: 190). Binbir Gece introduces an interesting twist by keeping Şehrazat's motherhood hidden from Onur. In later episodes when Şehrazat inevitably asks for the money from Onur, her new boss, without explaining why she needs the money, he looks on her as no different to all other traitorous women, rather than as a desperate mother who wants to save her child. Onur, who is suffering from Shahriyar syndrome despite his obvious affections for Şehrazat, would like to prove she is yet another worthless woman. After ridiculing her request by questioning why he, her new boss, should give her such a large amount of money, without asking why she needs it he offers to give her the money in exchange for a night with her.

This indecent proposal, which Şehrazat inevitably accepts in order to save her son's life, is what dominates Onur and Şehrazat's relationship right up to the end of the series. One could argue that this black night (siyah gece) that haunts their life is the modern interpretation of Shahriyar's killing of his brides after only one night. The theme of the indecent proposal in reference to the Nights is not a new concept. Joseph Roth in his 1939 book The Tale of the 1002nd Night used this device to portray the diminishing Austrian empire in late nineteenthcentury Vienna. In this story, the Shah of Persia visiting Vienna decides to sleep with a 
Viennese woman in addition to the numerous wives he already has at home, and chooses an honourable and married countess. The indecent proposal creates distrust in Şehrazat that remains with her to the end of the series. To heighten the intensity of their relationship, not long after the siyah gece, while on a work trip to Dubai for a project for which Şehrazat is a lead architect, Onur renews his proposal offering double the sum for another night together. This melodramatic device is what puts Şehrazat at an advantage over Onur, who clearly cannot admit his affection for her in an honest way. The issue is gradually resolved, however, through Onur's devotion to her in the first quarter of the episodes, especially when it is revealed that Şehrazat has a son and he is the reason she needs the money. Through different plot devices, Onur manages to assist her and convey his respect for her, to the point when she finally accepts his offer of marriage and they almost walk down the aisle together. At this point in the narrative another layer of conflict is introduced that brings back the memory of the siyah gece: Kerem also falls in love with Şehrazat. This eventually drives him to find out about the indecent proposal, which is revealed to everyone else much later in the story.

Şehrazat and Onur's first attempt to marry falls apart following the shameful act of a female employee — Jale (Nilüfar Silsüpür) — who was fired in the first episode because she had made sexual advances on Onur at work. On the day of their wedding she goes on television and claims she has left Binyapi because Onur offered her money to sleep with him. The sub-plot of the character of Jale is one that comes in and out of focus throughout the series and stems from a rival company that tries to take some business from Binyapi by ruining the firm's reputation.

From the little that has been told of Binbir Gece above, it is clear that this contemporary adaptation of the Nights is no longer the story of a mad king and the sacrificial Scheherazade who comes to cure him. In this appropriation of the frame story, Şehrazat is emancipated and no longer feels she is responsible for Onur's wellbeing as such, but she is 
after a mutually respectful relationship in which either party can retain their individuality, offering a modern twist on the original frame story. As in the frame story of the Nights, Şehrazat does not function as the storyteller; if anyone can be defined as the storyteller it is Onur. Many of the episodes before Onur and Şehrazat unite for the first time, end with Onur reading or reciting parts of One Thousand and One Nights, which function as a reflection on the events that had occurred in that episode.

\section{Binbir Gece: a Modern Adaptation}

While it may be more difficult to see Şehrazat as Scheherazade, Onur is very much the modern Shahriyar who, instead of ruling over an empire, rules over Istanbul's elite society. Another direct reference to the One Thousand and One Nights is the name he has chosen for his beloved horse, Şah Şehriyar. He is a keen rider and often escapes the city to look after his horse and ride in the woods. Jerome W. Clinton discusses Shahriyar's confrontation both of his wife's infidelity and of the fact that what has just become known to him has long been common knowledge in the court. The manner of her betrayal was such that not only was it perpetrated with the most subordinate figure in the palace, a black slave, but it also involved another forty male and female slaves from the court (Clinton 1985: 109). Clinton further argues that the source of Shahriar's fear and rage that led to his madness - employing one of many psychoanalytic theories — st ems from a "childhood trauma involving his mother and which included the essential elements of the later trauma that so disordered his wits' (Clinton 1985: 114). At the beginning of the Nights there is no mention of the queen, and Clinton equates this with the way the identities of the two brothers' wives have been reduced to their adulterous act, and asserts that this 'indicates a general denigration of women' (Clinton 1985: 114). Binbir Gece, set among the Istanbul socialites, has rendered this convoluted plot device similarly in two parts. The act of infidelity has affected Onur twice in his life, one as a child 
and once as an adult. He grew up with a father who had openly cheated on his mother and had died in his lover's bed. As an adult it is revealed to the viewer much later that Onur's fiancé has cheated on him. This second and personal betrayal has triggered his 'inner Shahriar' to come out. The Onur the viewers come to know at the beginning of the series mistrusts all women and engages in one-night stands without any sense of guilt. This is further highlighted when he reads the frame story of One Thousand and One Nights over and over again, sitting alone in his bachelor flat, while listening to Rimsky Korsakov's Scheherazade.

Besides being her namesake, Şehrazat also has many of Scheherazade's characteristics. She is constantly praised for her intellect and educational achievements (she is an awardwinning architect), and throughout the series, every time she leaves a job, she easily secures a new one in a matter of days and sometimes even hours. Şehrazat is an independent and very strong woman. She is an orphan with only an old sick aunt we never see, who lives in Ankara. Similarly, in the One Thousand and One Nights there is no mention of Scheherazade's mother or any siblings and one can assume the vizier has brought her up and treated her somewhat like a son, educated and independent. She possesses for women of that era an exceptional knowledge of poetry and history, and it is because of this knowledge that she can come up with a remedy and cure for the Shah's madness (Clinton 1985: 116). Although the curing function has also taken a new guise in Binbir Gece, Şehrazat teaches Onur about his wrongdoings by standing firm; at times it may seem that she is not very flexible and is not ready to compromise, especially if it forces her to lower her status.

Throughout the story Şehrazat functions as an ambassador for women. For example, on several occasions she helps women escape abusive relationships or advises her friends to act more decisively to overcome a particular hardship. In the apartment building where she used to live, a new bride is being regularly abused and beaten up. When Şehrazat selflessly gets involved, the first time the bride pretends everything is fine and sends her away, which makes 
Şehrazat very upset. But on another occasion, when the bride takes refuge in Şehrazat's flat, Şehrazat accepts her without a word and calls the police to deal with the man who was threatening them all.

Two kinds of women have been depicted in One Thousand and One Nights, representing good and evil. Both these types of women possess magical powers, but what matters is their intention and how they use, or abuse, their power. As Clinton argues, one of the messages that is repeated throughout the Nights is that if women are given reasonable security and protection they are 'quite happy to be guided by men in the exercise of their powers' (Clinton 1985: 121). This is in line with the Islamic belief that women, in exchange for respect and protection, are subordinated to men. One could argue that these defined gender roles are 'modernized' in Binbir Gece. Şehrazat struggles with both her ex-in-laws and later with Onur to receive the respect she deserves; she does not want to be caught in their patriarchal prison in the name of protection primarily because she does not want to be subordinate to any male figure (Clinton 1985: 121). While this struggle to stand on an equal footing remains one of the most important problems that keep Şehrazat and Onur apart until the very last episode, it is resolved relatively early on between Şehrazat and her ex-father-inlaw. One would expect a very traditional man like Burhan Evliyaoğlu, who lives in a mansion, to have asked Şehrazat and his grandson to move in with him in order to take care of them. But quite out of character, this old man not only does not force Şehrazat to change her lifestyle, he also finances her to open her own architectural firm once she no longer wants to work with Onur.

The theme of highly educated women is evident throughout the series, not only with positive characters like Şehrazat or Bennu (Ceyda Düvenci), Kerem's love interest, but it is made clear that the cunning women are also educated. This is also evident as a theme in One Thousand and One Nights, especially in the case of the slave girl characters such as Tawaddud 
who, like Scheherazade, 'claim woman's rightful place in society and proves female superiority in the domains of knowledge, sexuality, and status' (Marzolph 2007: 409). It is not only Şehrazat who is praised for her achievements; Bennu, another architect at the firm, who loves Kerem - the Shah Zaman character in Binbie Gece — is invited, albeit as part of a cunning plot, to be photographed for a magazine cover celebrating a successful female architect. Later, her oversized photos are displayed on billboards in the streets, visually putting her in a position of power.

There are two sides to this kind of tribute: the women who have not made a life for themselves are often judged in this series. Füsun, Şehrazat's ex-sister-in-law who married at a young age and who is a housewife with three children, is often put in a lower position than Şehrazat. Once Şehrazat has opened her own architectural firm, Füsun tells everyone that since she is very good at home decorating she will become an interior designer and share Şehrazat's office space. This idea is ridiculed several times by different members of the family, including her own brother, who is also staying with them to study at a university in Istanbul.

Among the recurrent themes in the stories of the One Thousand and One Nights are different forms of abduction. In many of the stories of the Nights kidnapping begins as the main theme of a given story; 'In terms of narrative strategy, the abduction represents the rupture of an idyllic harmony that in turn sets the narrative in motion' (Marzolph 2007: 466). Şehrazat is kidnapped twice in the series and both times, one way or another, it is done to force Onur to comply with a certain deal or simply to threaten him. In a very similar way, in the story Ali Shar and Zumurrud, a villain enters Ali Shar's house as a guest, drugs his host, and kidnaps Zumurrud, making Ali Shar attempt to rescue Zumurrud from her kidnapper's palace. In these stories, the abduction of a woman compels her lover to set off on a mission to rescue her; this functions as a narrative device to bring the story forward. 
One of the most intense abductions occurs in one of the sub-plots in Binbir Gece. Mihriban (Melahat Abbasova), the Azerbaijani lady who had donated bone marrow to Kaan and saved his life, has lived with Şehrazat and Kaan since the operation and works as his nanny. Through various conversations, it is known that Mihriban's brother in Azerbaijan has got involved with the wrong people and joined a gang. The brother runs away owing them money, they come to Istanbul, kidnap Mihriban and threaten to kill her unless he gives himself up. Besides adding action, this kidnapping brings Şehrazat and Onur closer together, because Mihriban is found and rescued through Onur's quick reaction and his connections with the police.

Another form of abduction depicted in Binbir Gece is caused not through malice but through love. Şehrazat's ex-brother-in-law's girlfriend, Cansel, leaves him while she is pregnant because she knows he would not leave his family for her and the child. She leaves Istanbul and goes back to her town. There by chance she is reunited with a high-school sweetheart, Yaman (teoman Kumbaracibasi), who also happens to be Onur's driver. They have a very brief but happy time together and after the baby boy is born, Yaman accepts him as his own and they get married. Unfortunately, soon after their marriage Cansel dies and Yaman, in an attempt to preserve her memory, runs away with the baby, while Ali Kemal and his family try to retrieve him and bring him home. This abduction functions as an emotional treatment of characters like Ali Kemal, who throughout the series have been acting irresponsibly and selfishly.

A recurring theme in One Thousand and One Nights that is shared with soap operas is that of cheating. This is the most recognizable storytelling device in One Thousand and One Nights that binds several tales together in a story cycle. Besides acts of infidelity and cheating in the frame story, many other tales consist of people cheating in order to help Shahriyar confront his demons and resolve his problem. In Binbir Gece both men and women at some 
point in the narrative cheat on their respective partners. What is interesting is that quite often the same character that has cheated on his partner is in turn cheated on at a later time. For example, Ali Kemal who has cheated on Füsun with Cansel, later in the narrative is cheated on by Füsun, who begins a relationship with their daughter's painting instructor. Bennu's sister Melek (Yeliz Akkaya), who admittedly has lived a promiscuous life, and had once even run away with Bennu's boyfriend, later in the story is cheated on by Burak (Mert Firat), Kerem's brother, who she was in a relationship with for most of the series. The cheating story cycles are the most tangled tales in Binbir Gece and perhaps some of the strongest plot devices to drive the narrative forward.

A subtle reference to one the most iconic One Thousand and One Nights story cycles is the reference to Sinbad the Sailor's character. Because of his closeness to Onur, Kerem is assumed to be Shah Zaman's counterpart, and is also a Sinbad figure. He owns a boat and lives on it until he marries Bennu. Only once in the series is the boat shown sailing on the sea, when he still believes he can win Şehrazat's love. There is a romantic boat ride with the two of them alone, but on this trip it is confirmed to him that she does not share his affections. Several times throughout the series he decides to leave everything behind and tour the world, especially when he finally realizes he cannot have Şehrazat, but every time something happens and he ends up staying. Only right at the end when Bennu decides to leave for America does he join her and leave everything behind, heading for a new adventure in a new land.

Another theme from One Thousand and One Nights that is explored in this soap opera is the presence of evil women alongside good women. Many elements of the famous story of Dalila from The Rogueries of Dalila the Crafty and Her Daughter Zaynab the Coney-Catcher are evident in Binbir Gece. One could argue that different elements from that tale are taken and applied to several characters in Binbir Gece. There are a few evil female characters in Binbir Gece but only three directly affect Şehrazat and Onur's life, namely Jale, Zeynap 
(Zeynep Konan), and Eda (Canan Erguder). Jale is the female architect who, because of her sexual advances on Onur, is fired in the first episode and later, with Onur's rival's support, comes on television to admit she has left Binyapi because Onur had offered her money to sleep with him, resulting in Şehrazat and Onur's break-up. Much later in the soap opera she comes back into the picture; this time Onur's rival kidnaps Şehrazat for a ransom. Jale, however, repents and helps Şehrazat escape, resulting in her own death. Zeynap, another employee who has left Binyapi, gets involved with Kerem; when Kerem tries to break it off she begins to manipulate him. After she is also fired she joins forces with Binyapi's rivals and attempts to spread a few rumours.

The third and worst of all evil women is Eda. In a very similar way to Dalila, Eda uses her cunning to achieve social advancement (Marzolph 2007: 164). Having made it into Şehrazat's social circle by getting a job at Binyapi, we learn little about her past and her relationship with Şehrazat. She comes from a small town and used to be in love with Şehrazat's deceased husband, Ahmet, before he met Şehrazat at university. Ahmet's family did not allow Eda and him to marry because she did not have a good reputation in the town. Later she stalks Ahmet, even going so far as to join the same university just a couple years below Şehrazat and Ahmet. When they marry without his family's consent Eda's hatred becomes so intense that even years after his death she tries to destroy her, because she sees Şehrazat as responsible for all her failings. She sweet-talks her way into getting hired at Binyapi and at firsts tries to lure Onur away, but his bond with Şehrazat has grown and they have recently got married. Later it is revealed that Şehrazat was pregnant and before it was too late they had decided to have a wedding ceremony. Eda who was trying to get closer to Şehrazat offers her a tea to calm her nerves, which causes her to have a miscarriage. Contrary to her expectations, this does not destroy their relationship but brings them closer together. She then contacts one of their former university professors, who was once in love with 
Şehrazat, and subcontracts some work from Binyapi to him. She creates false email accounts in his and Şehrazat's names and sends love emails to Şehrazat, which she responds to on her behalf. One day Şehrazat asks Onur to check something on her laptop; by chance Onur sees one of the emails, thus increasing his distrust of Şehrazat, but he says nothing about the incident and deletes the email. Behind Şehrazat's back Onur hires a private detective to shadow her and find out if she is cheating on him. While Eda can see her trick is working, she continues her deception and tries to persuade the professor to get involved. He rejects her idea and threatens to tell them what she has been doing; Eda kills him by pushing him off a building. Eda then later finds out that a construction worker has filmed the incident and in order to silence him, she also kills him by running him over in the street. She gets closer to Kerem who was having marital problems because Bennu had become very irritable after losing their baby. Eda exploits Kerem's vulnerability, and one drunken night Kerem speaks of his love for Şehrazat and adds that he knew Onur had given her the money in exchange for a night with her. Later Şehrazat finds out she is being followed, realizing it is Onur who has hired the private detective and that others know of what she has done for money, thinking Onur has told them. She is devastated, breaks all the furniture, and leaves, taking Kaan with her. Kerem subsequently tries to stop Eda and wants to break up with her, but she blackmails him; once she realizes he is not going to stop she tries to kill him and shoots him outside his house. Kerem survives but suspicion falls on Onur, because Kerem thinks Onur wanted to kill him because of revealing Şehrazat's sercret. Their childhood friendship is destroyed, the police continue to investigate and finally, the truth about Eda is revealed and she gasses herself in Kerem's garage.

Şehrazat begins a new life and a new job. Her new boss, an older divorcee with a teenage daughter, seems to be mature and calm and asks for her hand in marriage. Although it is evident Şehrazat does not love him she accepts his proposal. Kerem comes to tell Şehrazat 
the truth: he had found out about them because he had investigated who had come and gone in the hotel at the siyah gece night and not because Onur had told him. She in turn tells Onur that she knows the truth and she is beginning a new life, but on the night of the wedding, Kaan runs away to Onur's house and brings him to the wedding. Şehrazat, on seeing him at the door with the children, ${ }^{4}$ cannot go through with the wedding and walks towards Onur. Although it is a sad ending for the groom, Binbir Gece ends happily at least for the two main couples, bringing the One Thousand and One Nights frame story full circle. We also see Bennu, who has decided to leave Kerem and go to America to visit her mother, sitting on the plane when Kerem appears and sits beside her. They make it up and fly off together. Thus, after having their own melodramatic and turbulent relationship at the end of Binbir Gece, Kerem and Bennu are reunited as well. This is similar to the ending of most versions of One Thousand and One Nights where Shahzaman and Dunyazad, Scheherazade's sister, also marry at the end of the story.

There are many other sub-plots, with direct and indirect references to One Thousand and One Nights, involving Kerem and his family and the Evliyaoğlu family, which are beyond the scope of this article. But like many of the secondary tales in One Thousand and One Nights that do not come to a full resolution once the main story has moved on to another stage, neither do the other stories in Binbir Gece come to a resolution or an end, but are left open.

\footnotetext{
${ }^{4}$ Onur turns up at the wedding holding Kaan and Nilufer. Another sub-plot that this article does not discuss is the child that Onur's cheating fiancé, Nil, has left behind. Her mother's boyfriend brings the little girl, Nilufer, to Onur after she has died, telling him that she is their child. Supposedly, Onur had asked Nil to abort the baby once he realized she was cheating on her, but she had not done so. Despite him taking a genetic test, it is never very clear whether Nilufer is actually his child, but he loves her all the same.
} 
This open-endedness or the fact that many questions are left unanswered at the end of the story - except the principal character's — is one of the main characteristics of One Thousand and One Nights, which Binbir Gece shares with popular soaps internationally. Both soap operas and One Thousand and One Nights as the text and as a Turkish television series are embedded in popular culture. Both are uniquely open to feminist readings and make use of multiple layers of storytelling, the most specifically attributed characteristic of the Nights.

\section{Conclusion}

In conclusion, I would like to turn to the success of Binbir Gece in the world today, which very much resembles the wide reception of One Thousand and One Nights: first in its evolving cultures over many centuries, and then in the eighteenth and nineteenth centuries through its various translations into European languages. Turkish TV series and soap operas have always been very popular within the Middle East, along with their Egyptian and Indian counterparts. However, in recent years this popularity has surpassed the borders of the Middle East. Binbir Gece was officially sold to forty-six countries and, considering that the first season was made available with English subtitles on Netflix, we can assume it has extended to a much larger number of countries worldwide (William 2013: n.pag). Figure 1 is a map of Binbir Gece's reach throughout the world. As the series is only available with English subtitles on Netflix, I have included the English-speaking world that has access to Netflix but not the rest of Western Europe (which has equal access to the series via this platform). 


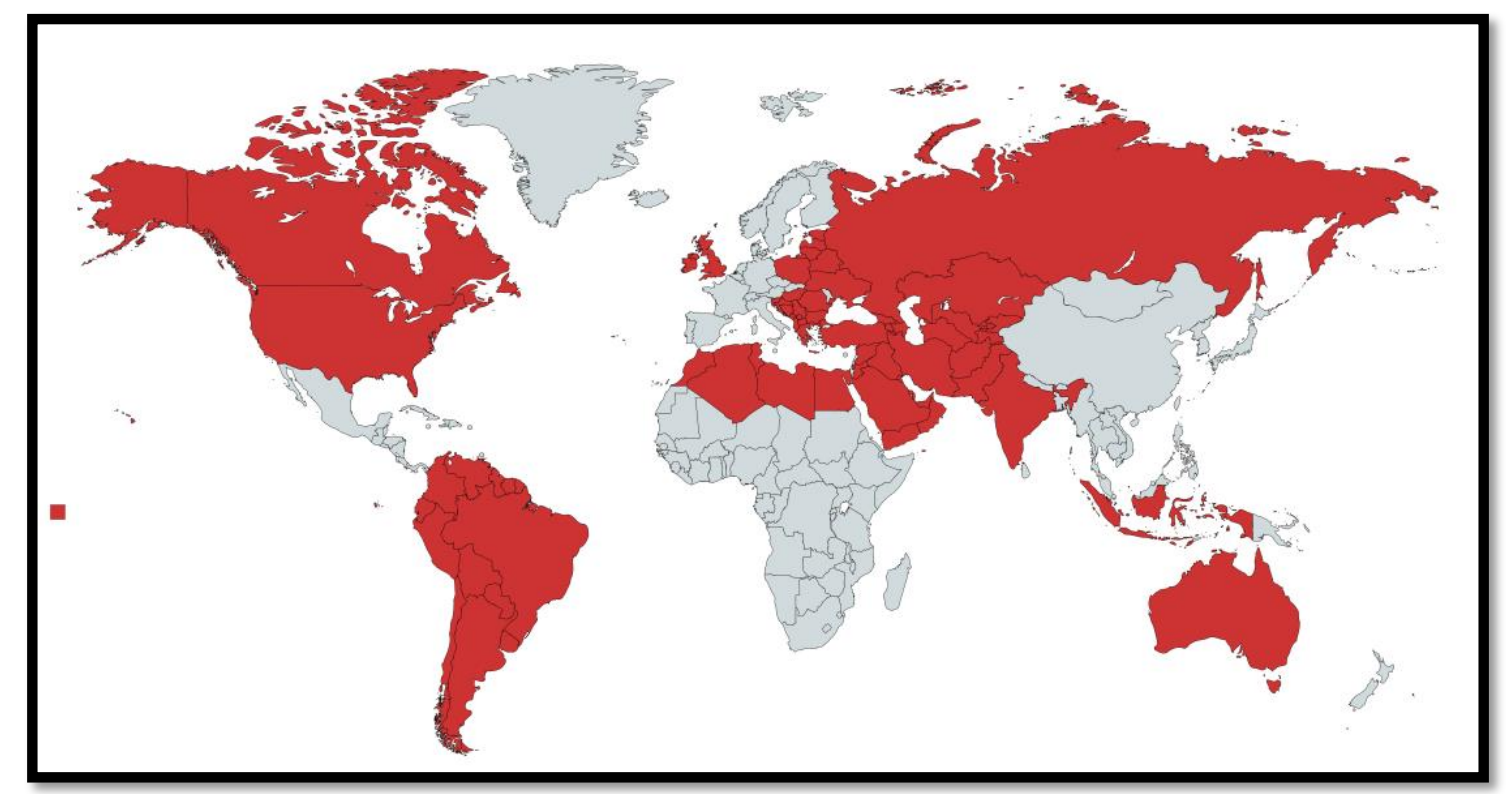

Figure 1: Binbir Gece Worldwide Distribution Map

It is noteworthy that the programme has found a market in South America, which has very popular and successful soap operas of its own. On social media, there are discussions of the trend sparked by Binbir Gece for 'Onur' and 'Şehrazat' as baby names in countries of this region (Lekka 2017). This trend is also evident in the Balkans, which is thought to reflect a sense of familiarity and shared heritage on the audience's part, owing to the Ottoman legacy in the region (Mihalakopoulos 2013:183). The increasing spread of Turkish TV soap operas as one of Turkey's main cultural products has aligned, albeit by chance, with Turkish Foreign Minister Ahmet Davutoğlu's soft-power strategy, outlined in 2001. He developed a pro-active and multi-dimensional foreign policy that would see 'Turkey's shared history and culture with former Ottoman lands as a strategic advantage — forming one prong of Turkey's soft-power strategy' (Mihalakopoulos 2013:183). It is reported that Turkey received a twelve per cent increase in the number of tourists from the countries that watched its TV series since 2005 (Mihalakopoulos 2013: 184).

This adaptation once again has popularised the classical tales of One Thousand and One Nights on a global scale. It has not only revived the Nights within its embedded cultures, 
but also extended them to a much larger international audience. What is fascinating is that despite its entertainment value and many overdramatised scenarios and events, it does stay true to some of the main moral teachings of the original text. Binbir Gece employs the two main characteristics of the Nights: embedded storytelling using a frame tale, and the 'feminist', emancipating heroine Scheherazade. Employing the soap-opera style, a suitable medium to deliver a multi-layered story such as One Thousand and One Nights, Binbir Gece has offered a fresh and contemporary adaptation of the frame story of Shah Shahriyar and Scheherazade, along with many nuanced elements from the different recurring themes and story cycles of the One Thousand and One Nights. In comparison with other recent free modern TV adaptations within the embedded cultures (Iran, Tukey and Egypt), Binbir Gece seems to have been the most successful, both in making direct references to the original text, and in achieving a global reach. Moreover, it is the most accessible, as no background knowledge is required to fully comprehend and enjoy what this series has to offer.

\section{Bibliography}

Al-Musawi, M. J. (2004), 'The "Mansion" and the "Rubbish Mounds": The Thousand and One Nights in Popular Arabic Tradition', Journal of Arabic Literature, 35: 3, pp. 329-67.

Behlil, M. (2010), 'Close Encounters?: Contemporary Turkish Television and Cinema', Wide Screen, 2: 2, pp. 1-14

Butler, J. G (1986), 'Notes on the Soap Opera Apparatus: Televisual Style and "As the World Turns",, Cinema Journal, 25: 3, pp. 53-70.

Celments, R. (1992), Aladdin (US: Walt Disney Pictures)

Clinton, J. W. (1985), 'Madness and Cure in the One Thousand and One Nights', Studia Islamica, 61, pp. 107-25. 
Emre Cetin, K. (2014), ‘The “Politicization” of Turkish Television Dramas', International Journal of Communication, 8: 22, pp. 2462-83.

Enderwitz, S. (2004), 'Shahrazâd Is One of Us: Practical Narrative, Theoretical Discussion, and Feminist Discourse', Marvels \& Tales, 18: 2, The Arabian Nights: Past and Present, pp. 187-200.

Freleng, F. (1982), 1001 Rabbit Tales (US: Warner Bros)

Grossman, J. (1980), 'Infidelity and Fiction: The Discovery of Women's Subjectivity in “Arabian Nights"”, The Georgia Review, 34: 1, pp. 113-26.

Kraidy, M. M. and Al-Ghazzi, O. (2013), 'Neo-Ottoman Cool: Turkish Popular Culture in the Arab Public Sphere', Popular Communication, 11:1, pp. 17-29.

Lekka, N. (2017), 'The Most Romantic Language? Turkish for Lovers', Babbel Magazine, 19 September, https://www.babbel.com/en/magazine/is-turkish-the-most-romanticlanguage. Accessed on July 25, 2019.

Lyons, M. C., Lyons, U. and Irwin, I. (2008), The Arabian nights: tales of 1001 nights, Volume 1, London: Penguin.

Malti-Douglas, F. (2006), 'Sharazad Feminist', in U. Marzolph (ed.), The Arabian Nights Reader, Detroit: Wayne State University Press, pp. 347-64.

Marzolph, U. (2007), The Arabian nights in Transnational Perspective, Detroit, Michigan: Wayne State University Press.

Marzolph, U. and van Leeuwen, R. (eds) (2004), The Arabian Nights Encyclopedia, Volume 1, Denver: ABC-CLIO.

Mihalakopoulos, G. (2013), 'The Greek audience "discovers” the Turkish soap-series: Turkey’s “soft power” and the psyche of Greeks', in. M. Tsianikas, N. Maadad, G. 
Couvalis and M. Palaktsoglou (eds), Greek Research in Australia: Proceedings of the Ninth Biennial International Conference of Greek Studies, Flinders University, June 2011, Adelaide, S. Australia: Flinders University, Department of Language Studies, pp.179-91.

Tania M. (1979), 'The Search for Tomorrow in Today's Soap Opera: Notes on a Feminine Narrative Form', Film Quarterly, 33: 1 (Fall), pp. 12-21.

Mulvey, L. (1989), 'Notes on Sirk and Melodrama' in L. Mulvey (ed.), Visual and Other Pleasures: Language, Discourse, Society, London, Palgrave Macmillan, pp. 39-44.

Nachbar. J. G., and Lausé, K. (ed.) (1992), Popular Culture: An Introductory Text, Bowling Green, OH: Popular Press.

Partovi, P. (2018), ‘Televisual Experiences of Iran’s Isolation: Turkish Melodrama and Homegrown Comedy in the Sanctions Era', Review of Middle East Studies, 52: 1, pp. $115-34$.

Pasolini, P. P. (1974), Il fiore delle mille e una note / Arabian Nights (Italy/France, United Artists).

Ritchie, G. (2019), Aladdin (US: Walt Disney Pictures).

Roth, J. (1939, 1999), The Tale of the 1002nd Night, trans. M. Hoffman, New York: St Martin's Press.

Şabanci, K. (2005), Anlat Istanbul/Istanbul Tales (Turkey: TMC Film)

Sallis, E. (1999), Sheherazade through the looking glass: the metamorphosis of the Thousand and One Nights, Richmond, Surrey: Curzon.

Starkey, P. (2006), Modern Arabic Literature, Washington D. C.: Georgetown University Press. 
Walsh, R. (1924), The Thief of Baghdad (UK: London Films).

We Love Istanbul (2019), ‘Maiden's Tower', We Love Istanbul, https://www.weloveist.com/listing/maidens-tower. Accessed 25 July 2019.

Williams, N. (2013), 'The Rise of Turkish Soap Power', BBC News, 27 July, https://www.bbc.co.uk/news/magazine-22282563. Accessed 25 July 2019.

\section{List of Television Programmes}

Binbir Gece (2006-2009, Turkey: Kanal D)

Shahrzad (2015-2018, Iran: Video Rental Services and Lotus Play)

Yabancı Damat (Foreign Groom) (2004, Turkey: Kanal-D)

\section{Contributor Details}

Maryam Ghorbankarimi is lecturer in film practice at Lancaster University. She completed her $\mathrm{PhD}$ in film studies at the University of Edinburgh in 2012 and her dissertation was published as a book entitled A Colourful Presence; The Evolution of Women's Representation in Iranian Cinema (Cambridge Scholar 2015). Her edited volume ReFocus: The Works of Rakshan Banietemad is coming out in March 2021 (Edinburgh University Press). Maryam is also a filmmaker; she has made some award-winning short films in both short documentary and fiction formats. Her current research is on transnational cinemas and cultures, specifically the representation of gender and sexuality in Iranian and other Middle Eastern cinemas.

\section{Contact: 33 River Street, Lancaster, LA1 1AD}

\section{Email: m.ghorbankarimi@lancaster.ac.uk}


Orchid number (if you have one): 0000-0003-2143-9867 